\title{
A Preliminary Occurrence of Extended-Spectrum and AmpC Beta-Lactamases in Clinical Isolates of Enteropathogenic Escherichia coli in Najaf, Iraq
}

Antibiotic resistance of EPEC isolates

By

\section{*Hashim Ali Abdulameer Alsherees Sumaya Najim Abed Ali}

\author{
Department of Microbiology / College of Medicine / University of Kufa
}

\section{Abstract}

Extended-spectrum $\beta$-lactamase (ESBL) and AmpC $\beta$-lactamase producing enteropathogenic Escherichia coli (EPEC) have become an important clinical problem due to their resistance to multiple antibiotics. The purpose of this study was to evaluate the multi-drug resistant (MDR) and $\beta$-lactamases producing EPEC isolated from children with diarrhea. Twenty two EPEC strains were gathered from another study performed from September to November 2009. Antibiotic susceptibilities against 20 antibiotics determined by the agar disk diffusion according to the protocol recommended by Clinical and Laboratory Standards Institute guidelines (CLSI). Phenotypic confirmatory tests carried out for screening of ESBLs and AmpC $\beta$-lactamase. The isolates subjected to PCR assays with specific primers for bla-genes $\left(b l a_{\mathrm{SHV}}, b l a_{\mathrm{TEM}}, b l a_{\mathrm{CTX}-\mathrm{M}}\right.$ and $b l a_{\mathrm{OXA}}, b l a_{\mathrm{PER}}, b l a_{\mathrm{VEB}}$ and $\left.b l a_{\mathrm{GES}}\right)$. Only $22(3.4 \%)$ EPEC isolates recovered from clinical infections. MDR rate in EPEC was $90.9 \%$. Phenotypic confirmatory tests showed that $13.6 \%$ and $20.0 \%$ of isolates were ESBL and AmpC $\beta$-lactamase producers, respectively. Among the EPEC isolates, percent recovery of bla $a_{\mathrm{SHV}}$, bla $a_{\mathrm{TEM}}, b l a_{\mathrm{CTX}-\mathrm{M}}$ and $b l a_{\mathrm{OXA}}$ genes was $100 \%, 81.8 \%, 77.3 \%$ and $9.1 \%$, respectively. Only $2(9.1 \%)$ isolates had $b l a_{\mathrm{AmpC}}$ gene and none of the isolates carried $b l a_{\mathrm{PER}}$, bla $a_{\mathrm{VEB}}$ and $b l a_{\mathrm{GES}}$ genes. The results of our study showed that the ESBLs were common among EPEC isolates. Such high dissemination of ESBLs is a serious problem for public health and therefore, it is necessary to seek a program for monitoring ESBLs in Najaf hospitals. This study is the first report on the presence of the bla-genes in EPEC isolates in Najaf.

Keyword: AmpC $\beta$-lactamase, ESBL, Enteropathogenic E.coli, Multi-drug resistant

\section{Introduction}


Enteropathogenic E.coli is an important cause of infantile diarrhea worldwide and particularly in developing countries ${ }^{[1]}$. There has been an alarming increase in drug-resistant strains of EPEC in developing as well as developed countries. Several cases of antimicrobial resistance in EPEC been observed in different parts of the world $^{[2]}$.

Extended-spectrum beta-lactamases [ESBLs) are the enzymes that hydrolyze a wide variety of $\beta$-lactam antibiotics including oxyimino-cephalosporins and monobactams but not cephamycins, and are usually inhibited by clavulanic acid. These ESBLs are derivatives, predominantly, of class A [e.g., TEM, SHV, CTX-M, and VEB families). These enzymes, encoded by genes that are typically plasmid borne ${ }^{[3]}$.

AmpC-mediated $\beta$-lactam resistance in E. coli is an emerging problem. High level AmpC production is typically associated with in vitro resistance to all $\beta$-lactam antibiotics except for carbapenems and cefepime. Genes for these $\beta$-lactamases found on the chromosomes of some members of the family Enterobacteriaceae ${ }^{[4]}$. Plasmid-mediated AmpC $\beta$-lactamase has arisen through the transfer of chromosomal genes for the inducible AmpC $\beta$-lactamases onto plasmids ${ }^{[5]}$. Plasmids with these genes can spread among other members of the family

Enterobacteriaceae, been documented in many countries and can cause nosocomial outbreaks ${ }^{[6]}$. Because of inappropriate usage of antibiotic in treatment of infection caused by ESBL producing pathogens, it seems that studies about correct detection and antibiotic resistance patterns of these organisms are necessary. However, there is no information regarding the molecular studies of ESBLs or the occurrence of AmpC $\beta$-lactamasesproducing EPEC isolates in Najaf, Iraq. For this reason, this study designed to estimate the presence of ESBLs and AmpC $\beta$-lactamases in EPEC isolates.

\section{Materials and Methods}

\section{Bacterial strains}

Twenty two EPEC strains were gathered from another study performed from September to November 2009 , that a total of 656 stool specimens from children younger than two years old with diarrhea were analyzed. E. coli isolates serotypically identified with EPEC polyvalent and monovalent antisera as previously described 


\section{Antibiotic susceptibility tests}

All strains were characterized by antimicrobial susceptibility testing for 20 antibiotics by disk diffusion method in accordance with the Clinical and Laboratory Standards Institute guidelines ${ }^{[8]}$. The following antibiotics (Himedia, India) were used: amoxicillin $(25 \mu \mathrm{g})$, amoxycillin/clavulanic acid $(20 \mu \mathrm{g} / 10 \mu \mathrm{g})$, amikacin $(30 \mu \mathrm{g})$, aztreonam $(30 \mu \mathrm{g})$, carbenicillin $(100 \mu \mathrm{g})$, ciprofloxacin $(5 \mu \mathrm{g})$, cefotaxime $(30 \mu \mathrm{g})$, ceftazidime $(30 \mu \mathrm{g})$, ceftriaxone $(30 \mu \mathrm{g})$, cefepime $(30 \mu \mathrm{g})$, cefoxitin $(30 \mu \mathrm{g})$, gentamicin $(10 \mu \mathrm{g})$, imipenem $(10$ $\mu \mathrm{g})$, levofloxacin $(5 \mu \mathrm{g})$, meropenem $(10 \mu \mathrm{g})$, piperacillin $(100 \mu \mathrm{g})$, tobramycin $(10 \mu \mathrm{g})$, ticarcillin $(75 \mu \mathrm{g})$, trimethoprim $(5 \mu \mathrm{g})$ and tetracyclin $(30 \mu \mathrm{g})$.

ESBL production detected by double-disk synergy test (DDST). Disks containing ceftazidime, cefotaxime, ceftriaxone and aztreonam respectively, placed $20 \mathrm{~mm}$ (center to center of the disks) from the amoxicillinclavulanic acid disk. Inoculated plates incubated aerobically at $37^{\circ} \mathrm{C}$ for $18 \mathrm{~h}$. After incubation, distortion of the inhibition zone of any of the antibiotics towards the disc containing clavulanic acid regarded as a phenotypic screening of the presence of ESBL ${ }^{[9]}$. ESBL production confirmed by both cefotaxime and ceftazidime alone and in combination with clavulanic acid. AmpC enzyme production tested by a modified three-dimension test (MTDT) as described by Coudron et al. ${ }^{[10]}$. E. coli strain 25922 (ATCC) was used as the reference strain.

\section{DNA isolation and polymerase chain reaction assays}

Enteropathogenic E. coli DNA extraction done according to Cheng and Jiang ${ }^{[11]}$ method. DNA templates subjected to PCR using six sets (F and R) of primers targeting bla genes listed in Table (1).

The reaction mixture moreover contain GoTaq® Green Master Mix, X2 (Promega M 7122; Promega Corporation, USA) and according to Promega procedure, the reaction mixtures were prepared in $0.2 \mathrm{ml}$ eppendorf tube with $25 \mu \mathrm{l}$ reaction volumes. PCR performed with PCR system (GeneAmp PCR system 9700; Applied Biosystem, Singapore). The PCR amplification conditions performed with a thermal cycler were specific to each single primer set (Table 1) depending on their reference procedure. The amplified PCR products detected by agarose gel electrophoresis and visualized by staining with ethidium bromide by UVtransilluminator. 


\section{Results}

Of the 656 diarrheal stools analyzed, 535 specimens yielded biochemically confirmed E. coli isolates, only $22(3.4 \%)$ agglutinated with EPEC antisera. The E. coli serotypes identified shown in Table (2). Twenty $(90.9 \%)$ isolates were resistant to a minimum of 3 classes of antibiotics, to which they were tested, hence the isolates are considered to be multidrug resistant (MDR) ${ }^{[12]}$. The resistant effect of isolates to carbenicillin amoxicillin piperacillin ticarcillin and amoxicillin/clavulanic acid are different. The rates of resistance were $90.9 \%$ for carbenicillin and $86.4 \%$ for others. It should be note that the highly diverse resistance rates against cephalosporins ranging from $59.1 \%$ to $77.3 \%$. High resistant rate for cefoxitin $(90.9 \%)$, most isolates were resistant to aztreonam (59.1\%). However, all the EPEC isolates were resistant to at least one of the cephlosporins or azetreonam. The most effective $\beta$-lactam antibiotics were imipenem and meropenem (100\% susceptible). Low rates of resistance to aminoglycosides amikacin, tobramycin and gentamicin were detected in isolates, $(0.0 \%),(4.5 \%)$ and $(9.1 \%)$, respectively, and all were susceptible to the fluoroquinolones tested Table (3).

All EPEC isolates were screened for ESBL production using DDST; results showed $3(13.6 \%)$ isolates were exhibited zones enhancement with clavulanic acid, confirming their ESBL production. The results confirmed that 20 isolates yield cefoxitin zone diameter less than $18 \mathrm{~mm}$ (screen resistance). These resistance isolates suspected as AmpC $\beta$-lactamase producers. The cefoxitin resistance isolates were further confirmed by the MTDT, a clear distortion of the zone of inhibition of cefoxitin indicating strong AmpC producer was observed in $4(20.0 \%)$ of the cefoxitin resistant isolates.

Table (2) shows the distribution of $\beta$-lactamases determined by the consistent results of primers specific PCR. All isolates carried at least one type of bla genes. The most commonly identified ESBL gene was bla $a_{\mathrm{SHV}}$ type $(100 \%)$, while $18(81.8 \%)$ isolates yielded amplification products with TEM-PCR specific primers. The presence of the bla $a_{\mathrm{CTX}-\mathrm{M}}$ gene detected in $17(77.3 \%)$ isolates. Only one isolate $(4.54 \%)$ carried $b l a_{\mathrm{OXA}}$ gene, and $2(9.1 \%)$ isolates were amplified with $b l a_{\mathrm{AmpC}}$ primers.

\section{Discussion}


A variety of antibiotics have been used to treat infection caused by EPEC and have proved useful in many cases, but multiple antibiotic resistances are common among EPEC. Many strains of EPEC known to harbor mobile elements that encode antibiotic resistance and can be transfer among themselves or to other bacterial species to establish multiple antibiotic resistances ${ }^{[17]}$.

In this study, the MDR rate of EPEC isolates evaluated against common antibiotics. Our results showed that MDR rate in EPEC was $90.9 \%$. These results confirmed data reported by other authors, indicating that EPEC are frequently and increasingly demonstrating multiple resistances to the antibiotics ${ }^{[1]}$. The high occurrence of MDR isolates of EPEC may be due to the widespread use of antibiotics in Najaf.

Our study revealed that all the EPEC isolates were resistant to at least one of the cephalosporin and azetreonam antibiotics. The high rates of resistance might be as markers for the production of ESBLs by these isolates. However, there are very few reports of ESBL production by diarrheagenic E. coli in the Middle East ${ }^{[17]}$. In Najaf, children with invasive diarrhea might be treat with third-generation cephalosporin, in view of the fact that the majority of EPEC isolates in this study were resistant to third-generation cephalosporins.

The study found that the frequency of ESBL-producing isolates was lower than a study accomplished in Hilla by Almohana et al. ${ }^{[19]}$ who indicates that ESBL production was confirmed in 36/82 (43.9\%) of E. coli. There is a number of instances whereby the screening tests for ESBLs are positive but the confirmatory tests negative or indeterminate ${ }^{[20]}$. Nonetheless, in this investigation not all screened positive EPEC isolates found to be ESBL producers. On the other hand, $86.4 \%$ of EPEC found to be resistance to amoxicillin/clavulanic acid, since clavulanic acid inhibits the ESBLs, reducing the level of resistance to the cephalosporins and thereby increasing the zone of inhibition for the disk diffusion tests. Resistance against $\beta$-lactamase inhibitors occurs mainly by several mechanisms: hyperproduction of $\beta$-lactamases, production of $\beta$-lactamases resistant to inhibitors, and chromosomal cephalosporinases ${ }^{[21]}$. In this study, DDST is a trustworthy, suitable and reasonably priced method of screening for ESBLs. However, this test can lack sensitivity because of problems of optimal disk spacing, the inability of clavulanate to inhibit all ESBL, the inability of test to detect ESBL in isolates that also produce chromosomal cephalosporinase and the loss of clavulanate disk potency during storage $^{[22]}$. 
Our results revealed that $81.8 \%$ of the isolates yielded amplification products with TEM-PCR specific primers. In Portugal, bla ${ }_{\mathrm{TEM}}$ gene identified in $85 \%$ isolates ${ }^{[23]}$. We found that all EPEC isolates harbored bla $_{\mathrm{SHV}}$ gene. . Additionally, $77.3 \%$ of the isolates harbored a bla $a_{\mathrm{CTX}-\mathrm{M}}$ gene. CTX-M constitutes a novel and rapidly growing type of plasmid-mediated ESBLs that is currently replacing mutant TEM or SHV ESBL families and which is much greater penetration into E. coli. In the Middle East area, reports from Lebanon and Kuwait pointed out that CTX-M is the predominant ESBL in E. coli ${ }^{[25]}$. Even though this may be due to the different antibiotics policies exist in various hospitals with excessive use of third generation cephalosporins. However, some risk factors of the acquisition of bla $a_{\mathrm{CTX}-\mathrm{M}}$ gene may be pressure from the surroundings by antibiotics. Results also revealed that only one isolates carried bla $a_{\mathrm{OXA}}$ gene.

Although, cefoxitin is not use in treatment of bacterial infections in Najaf hospitals, present investigation showed that $90.9 \%$ of EPEC isolates were cefoxitin resistant. The frequency of cefoxitin resistance in our study was higher than previously recorded in Iraq $(44.4 \%)$ by Almohana ${ }^{[19]}$. The study revealed that AmpC $\beta$ lactamase production confirmed by MTDT in $40 \%$ isolates. A limitation of methods used to detect the AmpC enzyme is that an increasing number of clinical isolates that have multiple $\beta$-lactamases, which in turn can make inhibition patterns complex and difficult to interpret ${ }^{[14]}$. There is no standardized method (such as synergy test for ESBL) to easily detect AmpC enzymes. Particularly, it is difficult in E. coli to distinguish phenotypically plasmid-mediated AmpC producers from isolates overproducing chromosomal enzymes at high levels. Additionally, a strain with a plasmid-mediated AmpC enzyme can also produce other $\beta$-lactamases, such as ESBL, which may complicate the detection of the AmpC phenotype ${ }^{[26]}$. PCR assay used in this study for the detection of bla $a_{\mathrm{AmpC}}$ gene that proved useful as screening tool to distinguish cefoxitin-resistant non-AmpC producer from cefoxitin-resistant AmpC producer isolate. The PCR assay confirms that only 2 of the 4 AmpC producer isolates previously identified in MTDT carried $b l a_{\mathrm{AmpC}}$ gene.

\section{Conclusion :}

It can be concluded that there is a respectively high occurrence of MDR and ESBL-producing EPEC isolates, as well as, high frequency of SHV producing isolates in our country. However, this is the first survey in 
Najaf hospitals. An important finding for physician in this study as presented in table 1, that the third generation cephalosporins may be not effective for treatment of all cases of EPEC infection in Najaf and the fourth generation cephalosporins and quinolones are the drugs of choices for these cases. This study also states the importance of carrying out sensitivity tests prior to treatment against the use of empirical treatment currently in practice in Najaf.

\section{References}

1. Mitra M, Ahmad P, Mehdil R, Hosein A and Ahmad, K. Multiple drug resistance of enteropathogenic Escherichia coli isolated from children with diarrhea in Kashan, Iran. African J Microbiol Res 2011; 5: 3305-3309.

2. Subramaniana K, Selvakkumara C, Vinaykumara KS, Goswamia N, Meenakshisundarama S, Balakrishnanb A and Lakshmia BS. Tackling multiple antibiotic resistance in enteropathogenic Escherichia coli (EPEC) clinical isolates: a diarylheptanoid from Alpiniaofficinarum shows promising antibacterial and immunomodulatory activity against EPEC and its lipopolysaccharide-induced inflammation. Int. J. Antimicrob Agents 2009; 33: 244-250.

3. Poole K. Resistance to beta-lactam antibiotics. Cell Mol Life Sci 2004; 61: 2200-2223.

4. Tan TY, Yong LS, He J, Koh TH. and Hsu LY. Evaluation of screening methods to detect plasmid-mediated AmpC in Escherichia coli, Klebsiella pneumoniae, and Proteus mirabilis . Antimicrob. Agents Chemoth 2009; 53: 146-149.

5. Walther-Rasmussen J and Hoiby N. Plasmid-borne AmpC beta-lactamases. Can J Microbiol 2002; 48: 479493.

6. Naseer U, Haldorsen B, Simonsen GS and Sundsfjord A. Sporadic occurrence of CMY-2-producing multidrug-resistant Escherichia coli of ST-complexes 38 and 448, and ST131 in Norway. Clin Microbiol Infect 2009; 16:171-178. 
bioRxiv preprint doi: https://doi.org/10.1101/512731; this version posted January 7, 2019. The copyright holder for this preprint (which was not

certified by peer review) is the author/funder, who has granted bioRxiv a license to display the preprint in perpetuity. It is made available under aCC-BY-NC-ND 4.0 International license.

7. Al-Hilali SA and Almohana AM. Occurrence and molecular characterization of enteropathogenic Escherichia coli serotypes isolated from children with diarrhoea in Najaf, Iraq. Indian J Med Microbiol 2011; 29(4): 383-8.

8. Clinical and Laboratory Standards Institute (CLSI). Performance standards for antimicrobial susceptibility testing; $20^{\text {th }}$. Informational Supplement. Approved standard M07-A8. Clinical and Laboratory Standards Institute, Wayne, Pa. 2010.

9. Bedenić B, Vraneš J, Bošnjak Z, Marijan T, Mlinarić-Džepina A, Kukovec T, Knežević J, Anušić M, Beader N, Barl P, Leskovar V and Kalenić S. Emergence of CTX-M group 1 extended-spectrum $\beta$-lactamaseproducing Klebsiella pneumoniae strains in the community. Med Glas 2010; 7: 32-39.

10. Coudron PE, Moland ES and Thomson KS. Occurrence and detection of AmpC $\beta$-lactamases among Escherichia coli, Klebsiella pneumoniae, and Proteus mirabilis isolates at a veterans medical center. J Clin Microbiol 2000; 38: 1791-1796.

11. Cheng HR and Jiang N. Extremely rapid extraction of DNA from bacteria and yeasts. Biotech Let 2006; 28: $55-59$

12. Eom J, Hwang B, Sohn J, Kim W, Kim M, Park S and Cheong H. Clinical and molecular epidemiology of quinolone-resistant Escherichia coli isolated from urinary tract infection. Microb Drug Resist 2002; 8(3): 227-234

13. Paterson DL, Hujer KM, Hujer AM, Yeiser B, Bonomo MD, Rice LB, Bonomo RA and the International Klebsiella Study Group. Extended-spectrum $\beta$-lactamases in Klebsiella pneumoniae bloodstream isolates from seven countries: dominance and widespread prevalence of SHV- and CTX-M-type $\beta$-lactamases. Antimicrob Agents Chemother 2003; 47: 3554-3560.

14. Kiratisin P, Apisarnthanarak A, Laesripa C and Saifon P. Molecular characterization and epidemiology of extended-spectrum- $\beta$-lactamase-producing Escherichia coli and Klebsiella pneumoniae isolates causing 
bioRxiv preprint doi: https://doi.org/10.1101/512731; this version posted January 7,2019 . The copyright holder for this preprint (which was not certified by peer review) is the author/funder, who has granted bioRxiv a license to display the preprint in perpetuity. It is made available under aCC-BY-NC-ND 4.0 International license.

health care-associated infection in Thailand, where the CTX-M family is endemic. Antimicrob Agents Chemother 2008; 52: 2818-2824.

15. Wang C, Cai P, Chang D and Mi Z. A Pseudomonas aeruginosa isolate producing the GES-5 extendedspectrum $\beta$-lactamase. J Antimicrob Chemoth 2006; 57(6):1261-1262

16. Karami N and Hannoun C. Colonization dynamics of ampicillin-resistant Escherichia coli in the infantile colonic microbiota. J Antimicrob Chemother 2008; 62: 703-708.

17. Usein C, Chitoiu D, Ciontea S, Condei M and Damian M. Escherichia coli pathotypes associated with diarrhea in Romanian children younger than 5 years of age. Jpn J Infect Dis 2009; 62: 289-293.

18. Sonnevend A, Al Dhaheri K, Mag T, Herpay M, Kolodziejek J, Nowotny N, Usmani A, Sheikh FA And Pal T. CTX-M-15-producing multidrug-resistant enteroaggregative Escherichia coli in the United Arab Emirates. Clin Microbiol Infect 2006; 12: 582-585.

19. Almohana AM and Al-Hilli ZB. Dissemination of beta-lactamases in Iraqi hospitals: molocular study of AmpC and carbapenemase producing bacteria. LAMBERT Academic publishing, USA. 2011.

20. Steward CD, Rasheed JK, Hubert SK, Biddle JW, Raney PM, Anderson GJ, Williams PP, Brittain KL, Oliver A, McGowan JE Jr, Tenover FC. Characterization of clinical isolates of Klebsiella penumoniae from 19 laboratories using the National Committee for Clinical Laboratory Standards extended-spectrum betalactamase detection methods. J Clin Microbiol 2001; 39: 2864-2872.

21. Espinasse F, Gheorghiu R, Poiata A, Labia R and Nicolas- Chanoine MH. Reduced susceptibility to coamoxiclav in Escherichia coli, Salmonella typhimurium and Klebsiella pneumoniae isolated in Romania between1985 and 1993. J Antimicrob Chemother 1997; 39: 103-106.

22. Moland ES and Thomson KS. Extended-spectrum $\beta$-lactamases of Enterobacteriaceae. J Antimicrob Chemother 1994; 33: 666-668. 
bioRxiv preprint doi: https://doi.org/10.1101/512731; this version posted January 7,2019 . The copyright holder for this preprint (which was not certified by peer review) is the author/funder, who has granted bioRxiv a license to display the preprint in perpetuity. It is made available under aCC-BY-NC-ND 4.0 International license.

23. Mendonca N, Leita o J, Manageiro V, Ferreira E, The antimicrobial resistance surveillance program in Portugal, and manuelacanic. Spread of extended-spectrum $\beta$-lactamase CTX-M-producing Escherichia coli clinical isolates in community and nosocomial environments in Portugal. Antimicrob Agents Chemother 2007; 51: 1946-1955.

24. Machado E, Cantơn R, Baquero F, Gala'n J, Rolla'n A, Peixe L, and Coque TM. Integron content of extended-spectrum- $\beta$-lactamase-producing Escherichia coli strains over 12 years in a single hospital in Madrid, Spain. Antimicrob Agents Chemother 2005; 49: 1823-1829.

25. Moubareck C, Daoud Z and Hakime N I, Hamzé M, Mangeney N, Matta H, Mokhbat JE, Rohban R, Sarkis DK, Doucet-Populaire F. Country wide spread of community and hospital-acquired extended-spectrum betalactamases (CTX-M15)-producing Enterobacteriaceae in Lebanon. J Clin Microbiol 2005; 43: 3309-3313.

26. Corvec S, Crémet L, Leprince C, Dauvergne S, Reynaud A, Lepelletier D and Caroff N. Epidemiology of Escherichia coli clinical isolates producing AmpC plasmidic $\beta$-lactamase during a 5-year period in a French teaching Hospital. Diagn. Microbiol. Infect Disease 2010; 67: 277-286. 
bioRxiv preprint doi: $\mathrm{https}$ //doi org/10.1101/512731; this version posted January 7, 2019. The copyright holder for this preprint (which was not certified by peer review) is the author/funder, who has granted bioRxiv a license to display the preprint in perpetuity. It is made available under aCC-BY-NC-ND 4.0 International license.

Table 1: Primer sequence for detection $\beta$-lactam resistance genes using PCR assay

\begin{tabular}{|c|c|c|c|c|c|c|c|}
\hline \multirow{2}{*}{$\begin{array}{l}\text { Primer } \\
\text { name }\end{array}$} & \multicolumn{2}{|c|}{ DNA Sequence(5'-3') } & \multicolumn{3}{|c|}{ PCR conditions (Temp/ sec) } & \multirow{4}{*}{$\begin{array}{l}\text { PCR } \\
\text { conditions } \\
822 \\
82\end{array}$} & \multirow{4}{*}{$\begin{array}{l}\text { reference } \\
14\end{array}$} \\
\hline & & & Denaturation & Annealing & Extension & & \\
\hline \multirow{2}{*}{$b l a_{\mathrm{TEM}}$} & $\mathrm{F}$ & AAACGCTGGTGAAAGTA & \multirow[t]{2}{*}{$94 / 30$} & \multirow{2}{*}{$45 / 60$} & \multirow{2}{*}{$72 / 1$} & & \\
\hline & $\mathrm{R}$ & AGCGATCTGTCTAT & & & & & \\
\hline \multirow[t]{2}{*}{$b l a_{\mathrm{SHV}}$} & $\mathrm{F}$ & ATGCGTTATATTCGCCTGTG & \multirow[t]{2}{*}{$94 / 30$} & \multirow[t]{2}{*}{$60 / 60$} & \multirow[t]{2}{*}{$72 / 1$} & \multirow[t]{2}{*}{753} & \multirow[t]{2}{*}{14} \\
\hline & $\mathrm{R}$ & TGCTTTGTTATTCGGGCCAA & & & & & \\
\hline \multirow{2}{*}{$b l a_{\text {CTX-M }}$} & $\mathrm{F}$ & CGCTTTGCGATGTGCAG & \multirow[t]{2}{*}{$94 / 30$} & \multirow[t]{2}{*}{$60 / 60$} & \multirow[t]{2}{*}{$72 / 1$} & \multirow[t]{2}{*}{550} & \multirow[t]{2}{*}{14} \\
\hline & $\mathrm{R}$ & ACCGCGATATCGTTGGT & & & & & \\
\hline \multirow[t]{2}{*}{$b / a_{A m p C}$} & $\mathrm{~F}$ & ATCAAAACTGGCAGCCG & \multirow[t]{2}{*}{$94 / 30$} & \multirow[t]{2}{*}{$60 / 60$} & \multirow[t]{2}{*}{$72 / 1$} & \multirow[t]{2}{*}{550} & \multirow[t]{2}{*}{14} \\
\hline & $\mathrm{R}$ & GAGCCCGTTTTATGCACCCA & & & & & \\
\hline \multirow[t]{2}{*}{$b l a_{\mathrm{GES}}$} & $\mathrm{F}$ & ATGCGCTTCATTCACGCAC & \multirow[t]{2}{*}{$93 / 60$} & \multirow[t]{2}{*}{$55 / 60$} & \multirow[t]{2}{*}{$72 / 1$} & \multirow[t]{2}{*}{846} & \multirow[t]{2}{*}{25} \\
\hline & $\mathrm{R}$ & CTATTTGTCCGTGCTCAGG & & & & & \\
\hline \multirow[t]{2}{*}{$b^{\prime} / a_{\mathrm{VEB}}$} & $\mathrm{F}$ & GCGGTAATTTAACCAGA & \multirow[t]{2}{*}{$93 / 60$} & \multirow[t]{2}{*}{$55 / 60$} & $72 / 1$ & 961 & 16 \\
\hline & $\mathrm{R}$ & GCCTATGAGCCAGTGTT & & & & & \\
\hline$b / a_{\mathrm{PER}}$ & $\mathrm{F}$ & AGTCAGCGGCTTAGATA & $93 / 60$ & $55 / 60$ & $72 / 1$ & 978 & 16 \\
\hline & $\mathrm{R}$ & CGTATGAAAAGGACAATC & & & & & \\
\hline$b^{\prime} a_{\text {OXA }}$ & $\mathrm{F}$ & ATATCTCTACTGTTGCATCTCC & $94 / 50$ & $55 / 50$ & $72 / 1$ & 619 & 17 \\
\hline & $\mathrm{R}$ & AAACCCTTCAAACCATCC & & & & & \\
\hline
\end{tabular}


bioRxiv preprint doi: https://doi.org/10.1101/512731; this version posted January 7, 2019. The copyright holder for this preprint (which was not certified by peer review) is the author/funder, who has granted bioRxiv a license to display the preprint in perpetuity. It is made available under aCC-BY-NC-ND 4.0 International license.

Table 2: Distribution of bla-genes in EPEC isolates

\begin{tabular}{|c|c|c|c|c|c|c|c|c|c|}
\hline \multirow{2}{*}{$\begin{array}{c}\text { Isolate } \\
\text { Designation }\end{array}$} & \multirow[b]{2}{*}{ Serotype } & \multicolumn{8}{|c|}{ Bla-gene } \\
\hline & & 耍 & $\stackrel{\sim}{\stackrel{n}{x}}$ & $\begin{array}{l}3 \\
\frac{1}{3}\end{array}$ & 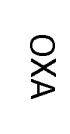 & 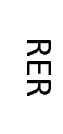 & 䛜 & 呬 & $\frac{p}{3}$ \\
\hline E1 & 0111:k58(B4) & + & + & + & - & - & - & - & - \\
\hline E2 & 044:k74(L) & + & + & + & - & - & - & - & - \\
\hline E3 & 0125:k70(B1)5) & + & + & + & - & - & - & - & - \\
\hline E4 & 055:k59(B5) & - & + & + & - & - & - & - & - \\
\hline E5 & 0125:k70(B1)5) & + & + & + & - & - & - & - & - \\
\hline E6 & 044:k74(L) & + & + & + & - & - & - & - & - \\
\hline E7 & 0128:k67(B1)2) & + & + & + & + & - & - & - & - \\
\hline E8 & 0127:k63(B8) & - & + & + & - & - & - & - & - \\
\hline E9 & 044:k74(L) & + & + & - & - & - & - & - & - \\
\hline E10 & 0111:k58(B4) & + & + & + & - & - & - & - & - \\
\hline E11 & O26:k60 (B6) & + & + & + & - & - & - & - & - \\
\hline E12 & 0111:k58(B4) & + & + & - & - & - & - & - & + \\
\hline E13 & 0111:k58(B4) & + & + & + & - & - & - & - & - \\
\hline E14 & O26:k60(B6) & - & + & - & - & - & - & - & - \\
\hline E15 & O55:K59(B5) & + & + & + & - & - & - & - & - \\
\hline E16 & O55:K59(B5) & + & + & + & - & - & - & - & - \\
\hline E17 & O55:K59(B5) & + & + & + & - & - & - & - & - \\
\hline E18 & UT (polyvalent 4) & + & + & + & - & - & - & - & - \\
\hline E19 & UT (polyvalent 2) & - & + & - & - & - & - & - & + \\
\hline E20 & 0114:k90(B) & + & + & + & - & - & - & - & - \\
\hline E21 & O55:K59(B5) & + & + & - & - & - & - & - & - \\
\hline E22 & O26:K60(B6) & + & + & + & - & - & - & - & - \\
\hline & Sum & 18 & 22 & 17 & 1 & 0 & 0 & 0 & 2 \\
\hline
\end{tabular}


bioRxiv preprint doi: https://doi.org/10.1101/512731: this version posted Januarv 7. 2019. The copvriaht holder for this preprint (which was not certified by peer review) is the author/funder, who has granted bioRxiv a license to display the preprint in perpetuity. It is made available under aCC-BY-NC-ND 4.0 International license.

Table 3: Frequency of antibiotics susceptibility of 22 EPEC isolates in Najaf.

\begin{tabular}{|c|c|c|c|}
\hline \multirow[t]{2}{*}{ Antibiotics } & \multicolumn{3}{|c|}{ EPEC isolates- } \\
\hline & Sensitive & Intermediate & Resistance \\
\hline Amoxycillin & $3(13.6 \%)$ & - & $19(86.4 \%)$ \\
\hline Piperacillin & $1(4.5 \%)$ & $2(9.1 \%)$ & $19(86.4 \%)$ \\
\hline Carbenicillin & $1(4.5 \%)$ & $1(4.5 \%)$ & $20(91 \%)$ \\
\hline Ticarcillin & $3(13.6 \%)$ & - & 19(86.4\%) \\
\hline Amoxyclav & $3(13.6 \%)$ & - & $19(86.4 \%)$ \\
\hline Cefotaxime & $6(68.2)$ & $1(4.5 \%)$ & $15(27.3 \%)$ \\
\hline Ceftazidime & $4(18.2 \%)$ & $2(9.1 \%)$ & $16(72.7 \%)$ \\
\hline Ceftriaxone & $9(59.1 \%)$ & - & $13(40.9 \%)$ \\
\hline Cefepime & $4(18.2 \%)$ & $1(4.5 \%)$ & $17(77.3 \%)$ \\
\hline Cefoxitin & $1(4.5 \%)$ & $1(4.5 \%)$ & $20(91 \%)$ \\
\hline Aztreonam & $9(40.9 \%)$ & - & $13(59.1 \%)$ \\
\hline Imipenem & $22(100 \%)$ & - & - \\
\hline Meropenem & $22(100 \%)$ & - & - \\
\hline Amikacin & $22(100 \%)$ & - & - \\
\hline Tobramycin & $21(95.5 \%)$ & - & $1(4.5 \%)$ \\
\hline Gentamicin & $10(45.5 \%)$ & $10(45.5 \%)$ & $2(9.1 \%)$ \\
\hline Ciprofloxacin & $22(100 \%)$ & - & - \\
\hline Levofloxacin & $22(100 \%)$ & - & - \\
\hline Trimethoprim & $5(22.7 \%)$ & $1(4.5 \%)$ & $16(72.7 \%)$ \\
\hline Tetracyclin & $11(50 \%)$ & - & $11(50 \%)$ \\
\hline
\end{tabular}

